\title{
Biomass of zooplankton and micronekton in the southern bluefin tuna fishing grounds off eastern Tasmania, Australia
}

\author{
J. W. Young*, R. W. Bradford, T. D. Lamb, V. D. Lyne \\ CSIRO Marine Laboratories, Division of Fisheries, GPO Box 1538, Hobart 7001, Tasmania, Australia
}

\begin{abstract}
The southern bluefin tuna (SBT) supports a seasonal fishery off the east coast of Tasmania, Australia. The distribution of zooplankton biomass in this region was examined as a means of finding out why the SBT are attracted to this area. We examined whether there was a particular area or depth stratum that supported significantly greater amounts of potential feed, directly or indirectly, for SBT Samples of zooplankton and micronekton were collected during the winter SBT fishery seasons in 1992-94. Five net types (mouth opening 0.25 to $-80 \mathrm{~m}^{2}$ ) with codend mesh sizes ranging from 100 to $1000 \mu \mathrm{m}$ were used. Samples were collected from 4 main hydrographic areas: warm East Australian Current water, cool subantarctic water, the front separating them (the subtropical convergence), and the adjacent shelf. Four depth strata $(50,150,250$ and $350 \mathrm{~m})$ were also sampled. In contrast to our expectations, the biomass in the subtropical convergence was no greater than that in the 3 other areas. Rather, it was the shelf, albeit with some inconsistencies, that generally had the greatest biomass of both zooplankton and micronekton. Offshore, there was no significant difference in the biomass of the depth strata sampled, although the biomass of gelatinous zooplankton in the surface waters increased during the study period. We suggest that the higher biomass on the shelf is the result of increased nutrients derived from a mixture of subantarctic water and upwelling along the shelf break. This biomass is converted via krill and gelatinous zooplankton to small pelagics such as jack mackerel, and finally to top predators, amongst which is SBT The SBT, particularly sub-adults, may time their migration eastward to take advantage of the concentrations of prey present at this time of year
\end{abstract}

KEY WORDS: Zooplankton - Micronekton · Biomass · Southern bluefin tuna

\section{INTRODUCTION}

It has long been known that tuna aggregate around oceanic features such as eddies and fronts, which are areas of high productivity (e.g. Dufor \& Stretta 1973. Shingu 1981, Laurs et al. 1984, Yamamoto \& Nishizawa 1986, Fiedler \& Bernard 1987, Roger 1994). Fronts are generally thought to have a greater phytoplankton abundance than adjacent waters (Loder \& Platt 1985, Peinert \& Miquel 1994). They may, therefore, support a higher zooplankton biomass through an increase in the phytoplankton stock (Thibault et al. 1994). For example, frontal waters may provide the best longterm average feeding conditions for herring Clupea

•E-mail: jyoung@ml.csiro.au harengus larvae (Kiorboe \& Johansen 1986). Presumably, therefore, fronts provide better feeding conditions for top predators. Both albacore Thunnus alalunga and skipjack Katsuwonus pelamis tuna feed extensively in frontal regions (Fiedler \& Bernard 1987).

Southern bluefin tuna Thunnus maccoyii (SBT) are fished off the east coast of Tasmania, Australia, on a seasonal basis. The fishing masters of tuna longline vessels loosely target the boundary between the subtropical waters of the East Australian Current (EAC) and the cooler subantarctic waters (SAW) to the south (the subtropical convergence, STC) for this species (Shingu 1981). However, we do not know why the SBT are attracted to the east coast of Tasmania. Does the STC provide a feeding ground of enhanced prey abundance or is it something else? 
Although the STC is targeted by longline fishers off the east coast of Tasmania, they are required to operate outside an $18.5 \mathrm{~km}$ (10 $\mathrm{n}$ mile) coastal exclusion zone. Inside this zone there is a small recreational southern bluefin troll fishery and a jack mackerel Trachurus declivis fishery (Williams et al. 1987). Both fisheries are restricted to the continental shelf waters of eastern and southern Tasmania. Jack mackerel-one of the main prey of SBT (J. W. Young, T. D. Lamb, D. Le, R. W. Bradford \& W. Whitelaw unpubl.) - is widely distributed over the shelf and shelf break/upper-slope region in autumn (Jordan et al. 1995), which is the start of the SBT longline fishing season. In addition, the shelf region supports a large biomass of the euphausiid Nyctiphanes australis, the main prey of jack mackerel (Young et al. 1993). Therefore, the shelf region may also influence the distribution of potential prey for SBT off Tasmania at this time.

The east coast of Tasmania has a complex hydrography. Warm filaments and eddies of the EAC meet cold SAW, creating a broad offshore front - the STC (after Wyrtki 1960) - with a surface temperature gradient of $\sim 2$ to $4^{\circ} \mathrm{C}$ (Fig. 1). The latitudinal position of this front varies both seasonally and annually (Harris et al. 1987. Young et al. 1993). On the shelf, apart from periodic intrusions of EAC water, a generally northward flow of SAW mixed with west coast water and river runoff produces a tongue of cold, nutrient-rich water, which can extend the length of the island (Cresswell et al. 1994).

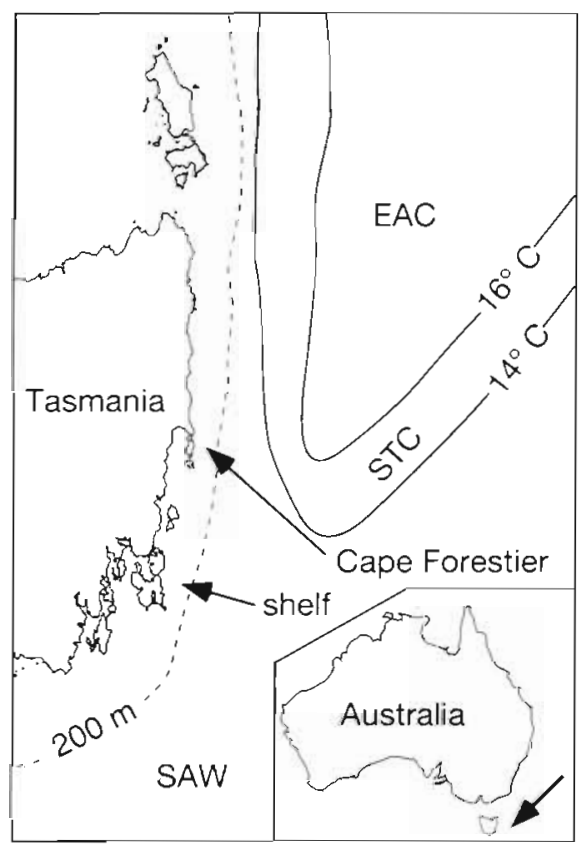

Fig. 1 Diagram of the main sampling areas. STC: subtropical convergence (sensu Wyrtkı 1960); EAC: East Australian Current; SAW: subantarctic water
Jack mackerel and other prey of SBT are highly mobile, so a quantitative description of their distribution is difficult. In this study, we have therefore examined the distribution of the biomass of prey of the prey of SBT, a technique successfully used by Roger (1994) on tropical tuna. Between 1992 and 1994, nets ranging from small plankton nets to midwater trawls were used to collect zooplankton samples off eastern Tasmania. Sea surface temperature satellite images at the start of the cruise periods and onboard water sampling enabled us to pinpoint the locations of the EAC, STC and SAW, and thus direct our sampling accordingly. We aimed, firstly, to find out whether there were differences in the biomass of zooplankton in the 4 hydrographic areas (EAC, STC, SAW and shelf) off eastern Tasmania. We then aimed to describe the pathway for the transfer of this biomass to top predators, in particular SBT.

\section{METHODS}

One cruise was completed each year in May/June of 1992, 1993 and 1994 on CSIRO FRV 'Southern Surveyor' $(66.1 \mathrm{~m})$ off the east coast of Tasmania. These cruises were timed to coincide with the autumn/winter longline fishery for SBT. The physical oceanography of the area was described from a series of tramsects that encompassed EAC water (temperature $T>16^{\circ} \mathrm{C}$ ), SAW $\left(T<14^{\circ} \mathrm{C}\right)$, the STC $\left(14^{\circ} \mathrm{C} \leq T \leq 16^{\circ} \mathrm{C}\right)$ and the shelf ( $\leq 200 \mathrm{~m}$ depth) (Fig. 1). On each transect conductivitytemperature-depth (CTD: Neil Brown MK IIIB WOCE) casts to $400 \mathrm{~m}$ recorded temperature, salinity, density and nutrients $\left(\mathrm{NO}_{3}\right.$ and $\left.\mathrm{PO}_{4}\right)$. In 1992 and 1993 a SeaBird fluorometer was used to give an indication of chlorophyll a to a depth of $150 \mathrm{~m}$. In 1994 fluorescence was recorded directly from the CTD. The oceanographic transects were also used to ground-truth satellite images (Advanced Very High Resolution Radiometer, aboard NOAA's TIROS-N series of satellites) of sea surface temperature taken of the area during each cruise

Net collections. Five net types were used to sample the zooplankton off the east coast of Tasmania (Table 1). Microzooplankton (animals from $20 \mu \mathrm{m}$ to $2 \mathrm{~mm}_{\text {; }}$ classification of Omori \& Ikeda 1984) was sampled with a drop net (Heron 1982) of mesh size $100 \mu \mathrm{m}$ and mouth area $0.25 \mathrm{~m}^{2}$ at each of the hydrographic stations (Fig. 2). This net sampled to $100 \mathrm{~m}$ except on the shelf, where it sampled to $60 \mathrm{~m}$.

Macrozooplankton (animals from 2 to $20 \mathrm{~mm}$ ) was sampled at night $(19: 00$ to $04: 00 \mathrm{~h})$ with a multiple opening/closing BIONESS net (mouth opening $1 \mathrm{~m}^{2}$ ) in 1992 and 1993. The frame was fitted with multiple nets of $335 \mu \mathrm{m}$ mesh. Depth and net-trip time were 
Table 1 Net type, mesh size and number of samples collected off the east coast of Tasmania. SAW: subantarctic water; STC: subtropical convergence; EAC: East Australian Current. See Fig. 2 for station positions

\begin{tabular}{|lccrrrrr|}
\hline Net type & Year & $\begin{array}{c}\text { Mesh } \\
(\mu \mathrm{m})\end{array}$ & \multicolumn{6}{c}{$\begin{array}{c}\text { No. of samples per region } \\
\text { SAW }\end{array}$} & STC & EA.C & Shelf & $\begin{array}{c}\text { Maximum } \\
\text { depth (m) }\end{array}$ \\
\hline Drop net & 1992 & 100 & 26 & 36 & 19 & 22 & 100 \\
& 1993 & 100 & 19 & 7 & 24 & 6 & 100 \\
& 1994 & 100 & 3 & 21 & 2 & 24 & 100 \\
BIONESS & 1992 & 335 & 7 & 7 & 2 & 4 & 400 \\
& 1993 & 335 & 5 & 5 & 5 & 3 & 400 \\
Bongo net & 1994 & 1000 & 26 & 17 & 15 & 11 & 200 \\
Surface net & 1992 & 1000 & 20 & 11 & 13 & 17 & $<5$ \\
& 1993 & 1000 & 19 & 16 & 14 & 13 & $<5$ \\
IYGPT & 1994 & 1000 & 20 & 30 & 24 & 17 & $<5$ \\
& 1992 & Trawl & 9 & 12 & 3 & 5 & 400 \\
& 1993 & Trawl & 10 & 6 & 6 & 2 & 400 \\
& 1994 & Trawl & 3 & 2 & 4 & 1 & 400 \\
\hline
\end{tabular}

Laboratory analysis. Microzooplankton samples were dried for $24 \mathrm{~h}$ at $60^{\circ} \mathrm{C}$ and weighed $( \pm 0.05 \mathrm{~g})$. Macrozooplankton samples were sorted into fish, cephalopods, crustaceans, and gelatinous zooplankton. A wet weight for each group was recorded. The crustacean fraction was split once with a Folsom splitter and one half was returned to the jar; the other half was dried at $60^{\circ} \mathrm{C}$ for $24 \mathrm{~h}$ or until constant weight was achieved. Micronekton samples were sorted to species level where possible, counted and (wet) weighed. Crustaceans and gelatinous zooplankton were weighed separately.

Where samples were required for identification, dry weight was estimated from wet weight using a conversion factor (Table 2). Replicate samples of represen-

transmitted to the surface via a conducting tow cable. Each tow consisted of an oblique tow to $400 \mathrm{~m}$ followed by oblique tows for $20 \mathrm{~min}$ each at depths of $400-300 \mathrm{~m}, 300-200 \mathrm{~m}, 200-100 \mathrm{~m}$ and $100 \mathrm{~m}$ to the surface. Macrozooplankton was sampled by day in 1994 with a paired $70 \mathrm{~cm}$ bongo net (a previous study had shown no difference in the biomass of krill from daytime and nightime samples over the Tasmanian shelf; Young et al. 1993). Volume filtered was recorded with a flowmeter. A submersible data logger attached to the frame transmitted depth, rate of descent and elapsed fishing time. The bongo net fished obliquely from the surface to $200 \mathrm{~m}$ and back again over about $20 \mathrm{~min}$.

To sample the surface macrozooplankton, a square surface net (mouth area $1 \mathrm{~m}^{2}$ and $1000 \mu \mathrm{m}$ mesh) fitted with a mechanical flowmeter was deployed with each BIONESS, bongo and IYGPT (International Young Gadoid Pelagic Trawl) midwater trawl net from a $3 \mathrm{~m}$ davit rigged amidships.

Micronekton (animals between 2 and $20 \mathrm{~cm}$ ) was sampled at night (19:00 to 04:00 h) with an IYGPT midwater trawl (mouth area $1 \mathrm{~m}^{2}$, mesh size $1000 \mu \mathrm{m}$ ) (see Young \& Blaber 1986) fitted with an opening/closing codend (Pearcy et al, 1977). The codend had an electronic timer to trip nets at set times. Depth, mouth opening, headline height and board spread of the trawl were monitored acoustically. In 1992 and 1993 the sampling pattern followed that for the BIONESS net, with a 40 min oblique tow to $400 \mathrm{~m}$, followed by 20 min oblique tows at depths of 400-300, 300-200, 200-100 and 100-0 m. During 1994, the midwater trawl was set to fish two 40 min oblique tows: surface to $400 \mathrm{~m}$ and $400 \mathrm{~m}$ to surface.

All samples were fixed in $10 \%$ formalin in seawater buffered with sodium acetate. tative taxa were (wet) weighed and then dried at $60^{\circ} \mathrm{C}$ for $24 \mathrm{~h}$ and an average value was used as the conversion factor of wet weight to dry weight. Dry weights were used in all analyses. Our values for dry weights of the main prey taxa corresponded to values established by other researchers (see for example Wissing et al. 1973, Wiebe et al. 1975, Omori \& Ikeda 1984. Heron et al. 1988).

Data analysis. Volume filtered by the drop net was calculated by multiplying the depth sampled by the area of the mouth opening. Volume filtered $(V)$ by the surface and bongo nets (in $\mathrm{m}^{3}$ ) was calculated from the equation $V=D A$ where $D$ is distance travelled (calculated from the flowmeter readings) and $A$ is net mouth area $\left(\mathrm{m}^{2}\right)$. Volume filtered by the BIONESS and midwater trawl nets was calculated by the equation $V=S \cdot d \cdot A$, where $S$ is ship's speed $\left(\mathrm{m} \mathrm{s}^{-1}\right)$ and $d$ is duration of tow (s). Microzooplankton were expressed as $\mathrm{g}$ dry wt per $100 \mathrm{~m}^{3}$, macrozooplankton were expressed as g dry wt per $1000 \mathrm{~m}^{3}$, and micronekton as $g$ dry wt per $100000 \mathrm{~m}^{3}$ Fluorescence was expressed as standardised fluorescence units (FU) and was taken as an index of phytoplankton biomass.

Comparisons of biomass between years, area and depth were made with a multiway ANOVA (SYSTAT). All data were transformed to $\log _{e}$ (dry weight +1 ), as

Table 2. Conversion factors used to convert wet weight to dry weight for the 4 main taxa

\begin{tabular}{lc|}
\hline Group & Conversion \\
\hline Pisces & 0.244 \\
Cephalopoda & 0.128 \\
Crustacea & 0.171 \\
Gelatinous zooplankton & 0.034 \\
\hline
\end{tabular}




\section{Hydrographic and microzooplankton stations}

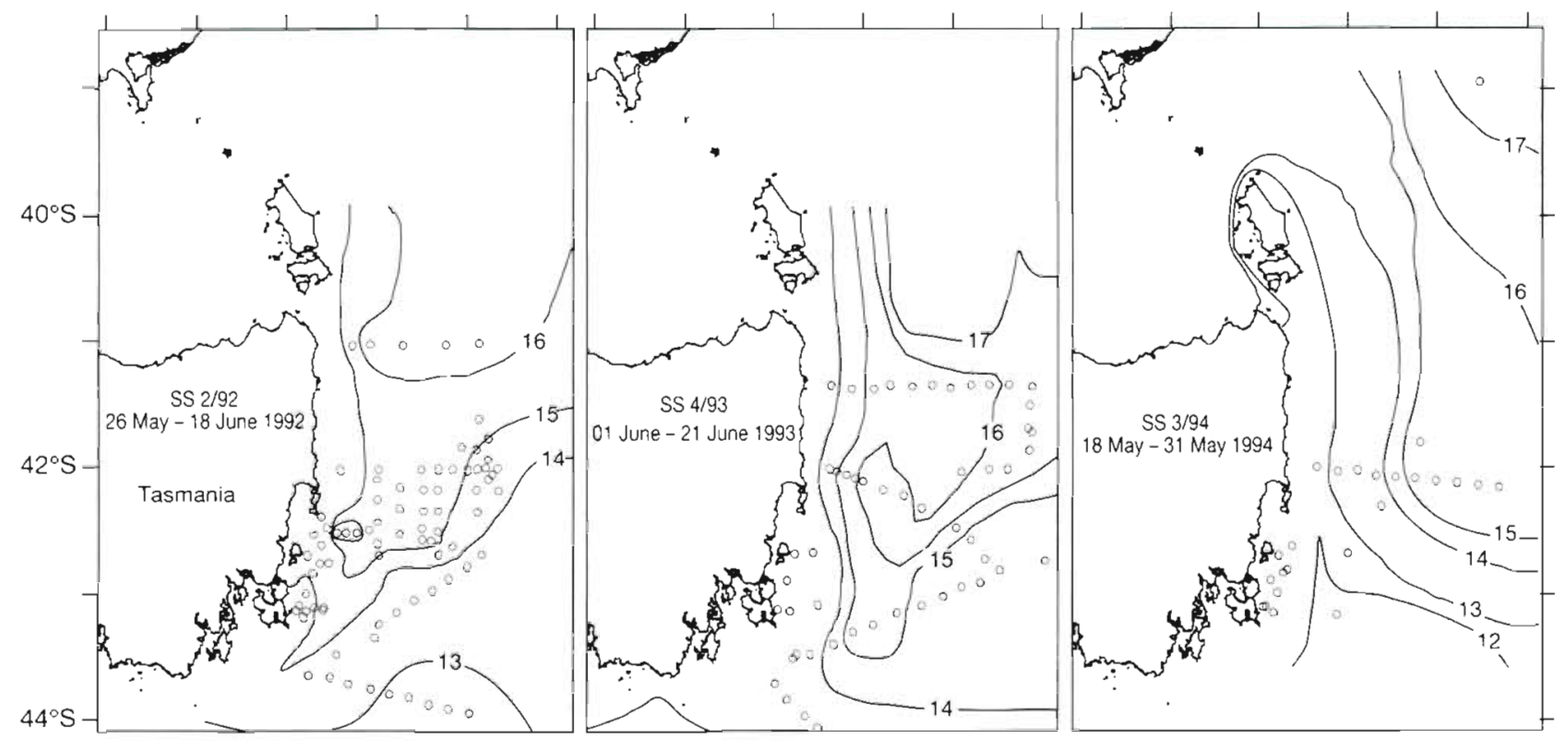

Macrozooplankton and micronekton collection sites

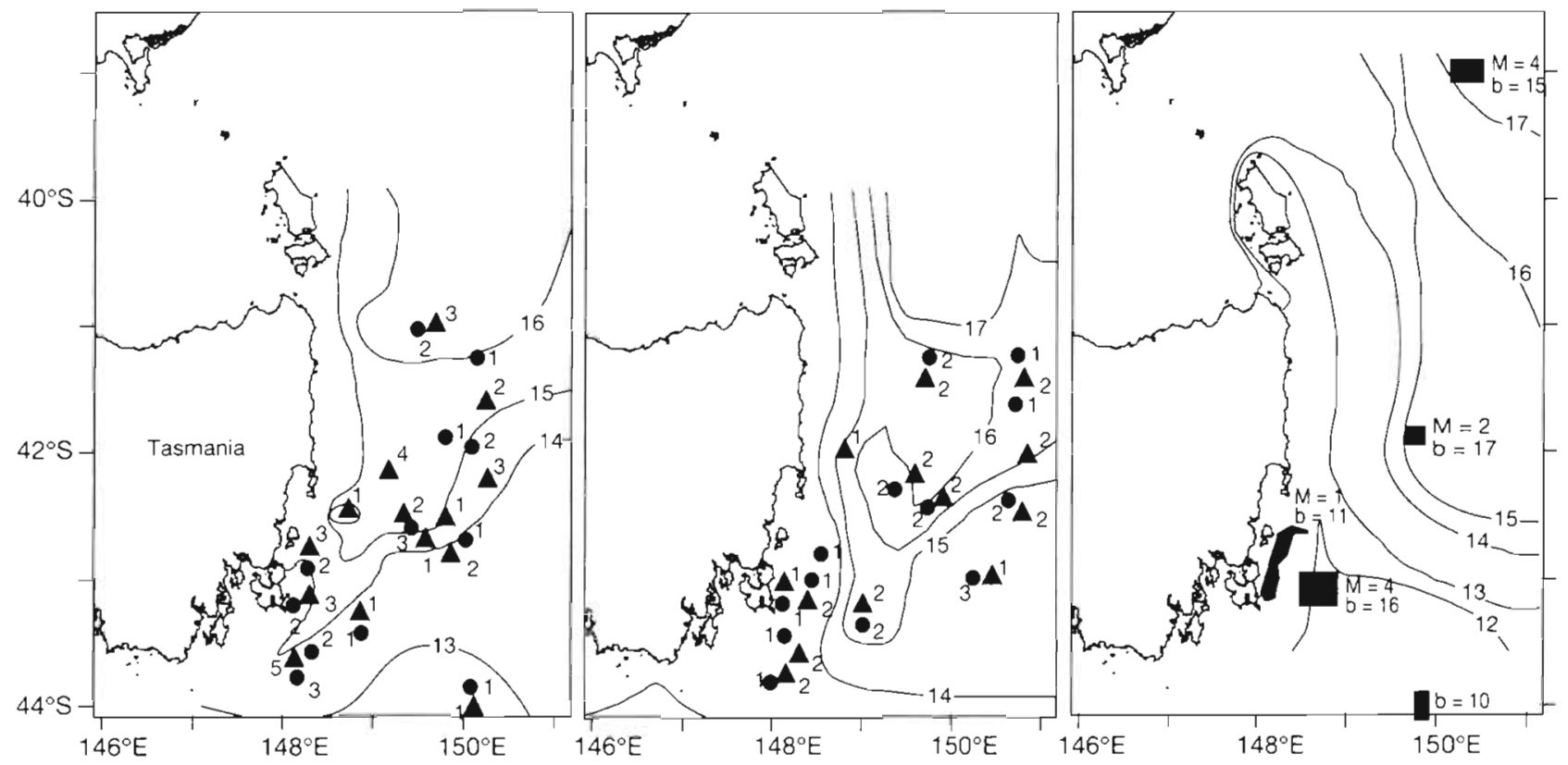

Fig. 2. Station positions for the 3 cruises off eastern Tasmania, Australia. (0) CTD/drop net stations; (A) IYGPT midwater trawl stations; (-) BIONESS stations. M: IYGPT midwater trawI; b: bongo net (number of stations shown). Surface net samples were collected at each [YGPT midwater trawl, BIONESS and bongo net station. Isotherms refer to temperature in ${ }^{\circ} \mathrm{C}$

this transformation gave the most even distribution of residuals versus fitted values. A Tukey post hoc test was used to distinguish between groups (Zar 1984). Generally, this test was used when the effects were significant at $p \leq 0.05$, but was also used when a trend was detected ( $p<0.1$ level). Depth comparisons apply to offshore samples only.

\section{RESULTS}

\section{Physical oceanography}

In June 1992, satellite imagery and our hydrographic data showed a wedge of warm East Australian Current (EAC) water extending down the eastern Tasmanian 
shelf to about $43^{\circ} \mathrm{S}$. Offshore a broad front (between 14 and $15^{\circ} \mathrm{C}$ ) was present on a NE-SW axis (Fig. 2). To the south, colder subantarctic water (SAW) was present. The following year the EAC was slightly warmer but was further offshore, possibly the result of a cool tongue of SAW pushing northward along the shelf (Fig, 2). Satellite-tracked drifter buoys released in 1992 and 1993 off the west coast of Tasmania identified a current of west coast water on the continental shelf moving eastward (Cresswell et al. 1994). The front was much broader and less intense in 1993 than in 1992. In 1994 the shelf was dominated by a mixture of colder SAW and west coast water (Fig. 2). The front was most pronounced in 1994 with a $\sim 4^{\circ} \mathrm{C}$ change in surface water temperature over approximately $90 \mathrm{~km}$.

Vertical cross-sections constructed from CTD casts eastward of Cape Forestier (Fig. 1) over the 3 years revealed the presence of 2 main fronts: one at the shelf break and one between EAC and subantarctic waters 120 to $160 \mathrm{~km}$ east of the coast (Fig. 3). The intensity of the shelf-break front was less pronounced in 1994 when SAW was more prevalent generally. The EAC was restricted largely to the upper $200 \mathrm{~m}$ of the water column, although sloping of isotherms indicated its influence extended to at least $400 \mathrm{~m}$. The nitrate, phosphate and fluorescence transects indicated upwelling of nutrients along the shelf break and subtropical convergence (STC) in 1992 and 1993 (Fig 3). In 1994 nutrient levels were generally higher, reflecting the dominance of SAW at this time.

\section{Net sampling}

A total of 209 drop net, 38 BIONESS, 69 bongo, 214 surface net and 63 IYGPT midwater trawl samples were taken over the 3 years (Table 1). The biomass of microzooplankton ranged from 0 to $172.19 \mathrm{~g}$ per $100 \mathrm{~m}^{3}$ $[\bar{x}( \pm \mathrm{SE})=2.26 \pm 1.02]$. Macrozooplankton samples ranged in biomass from 0 to $373.84 \mathrm{~g}$ per $1000 \mathrm{~m}^{3}$ $(\bar{X}=6.29 \pm 1.07)$. Micronekton samples ranged from 0.67 to $21301.20 \mathrm{~g}$ per $100000 \mathrm{~m}^{3}(\bar{x}=476.91 \pm 336.94)$.
Euphausia similis var. armata and E. spinifera (R. Bradford unpubl. data). Shelf catches were dominated by the euphausiid Nyctiphanes australis. A total of 109 species of fish identified from offshore consisted largely of myctophid and stomiatoid species (Young et al. in press). Only 38 fish species, of which jack mackerel Trachurus declivis was the main one, were identified from the shelf. The squid fraction was dominated by Lycoteuthis lorigera, Abraliopsis gilchristi and Histioteuthis spp. offshore, and by Nototodarus gouldi and Euprymna tasmanica over the shelf.

\section{Interannual differences in biomass}

Overall, biomass was generally lowest in 1992 and highest in 1994 (Fig. 4a). Microzooplankton biomass changed little from 1992 to 1993. An increase from 1993 to 1994 was not statistically significant (Table 3, Fig. 4a). Similarly, there was little difference in the biomass of macrozooplankton and surface macrozooplankton between 1992 and 1993. Although we were unable to collect BIONESS samples in 1994, the surface net samples showed an increase in that year. Micronekton biomass increased over the 3 years (Fig. 4a)

The main taxa were not separated in the microzooplankton samples. The composition of the BIONESS net samples, which contained mainly crustaceans, did not differ between years (Fig. 4b). In contrast, the surface macrozooplankton samples, mainly crustaceans in 1992, were largely composed of gelatinous zooplankton by 1993 and 1994 (Fig. 4b). Fish taxa dominated the micronekton in 1992. However, the proportion of fish biomass decreased over the following years, while gelatinous zooplankton increased.

\section{Distribution of biomass by area}

Microzooplankton (drop net). The biomass of microzooplankton did not differ significantly between years despite it being greater in 1994 (Fig. 4a). However, there

\section{Composition of biomass}

The biomass was composed of 4 broad taxa: gelatinous zooplankton, crustaceans, fish and squid. Of these, gelatinous zooplankton consisted largely of the salps Thalia democratica and Thetys vagina, and pyrosomes. The crustacean fraction from offshore waters consisted mainly of the decapods Sergestes (Sergia) prehensilis, S. (Sergia) potens, S. (Sergestes) arcticus, Acanthephyra quadrispinosa and Gennadas spp., and the euphausiids
Table 3. Comparisons between years, areas and their interactions of the 5 main biomass groupings off eastern Tasmania using multiway ANOVA (-: no test; bongo nets were used only in 1994, therefore there is no comparison between years)

\begin{tabular}{|c|c|c|c|c|c|c|c|c|c|}
\hline \multirow{3}{*}{ Net type } & \multirow{2}{*}{\multicolumn{3}{|c|}{ Year }} & \multicolumn{3}{|c|}{ Effect } & \multirow{2}{*}{\multicolumn{3}{|c|}{ Year $\times$ Area }} \\
\hline & & & & & Area & & & & \\
\hline & df & $F$-ratio & $\mathrm{p}$ & df & $F$-ratio & $\mathrm{p}$ & $d f$ & $F$-ratio & $\mathrm{p}$ \\
\hline Drop net & 2 & 0.62 & 0.54 & 3 & 4.94 & 0.00 & 6 & 3.76 & 0.00 \\
\hline BIONESS & 1 & 1.38 & 0.25 & 3 & 0.28 & 0.84 & 3 & 1.56 & 0.22 \\
\hline Bongo net & - & - & - & 3 & 4.76 & 0.01 & - & - & - \\
\hline Surface net & 2 & 0.16 & 0.85 & 3 & 3.32 & 0.02 & 6 & 2.40 & 0.03 \\
\hline IYGPT & 2 & 13.31 & 0.00 & 3 & 4.94 & 0.00 & 6 & 1.44 & 0.22 \\
\hline
\end{tabular}



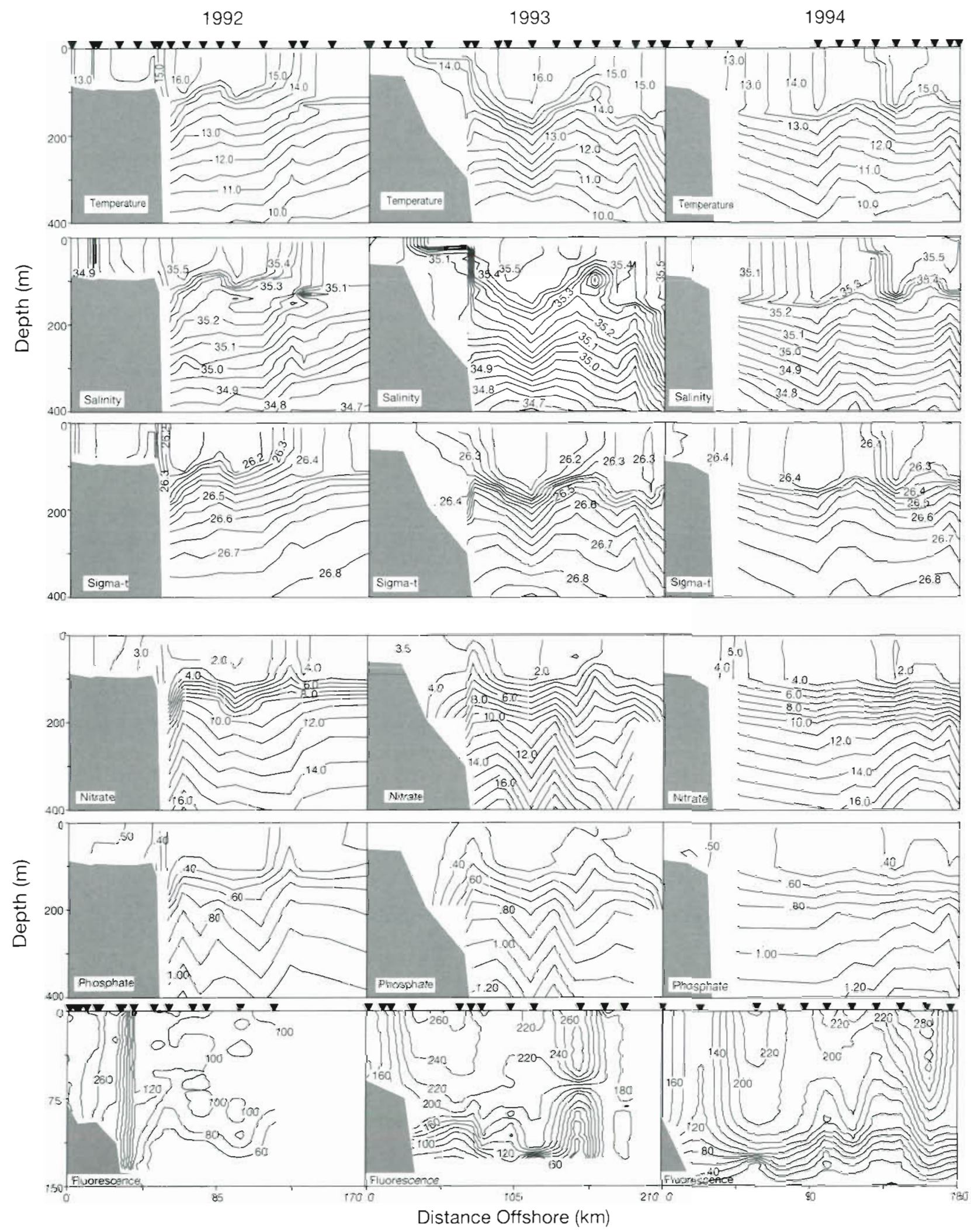

Fig. 3. Vertical cross-sections of the water column to $400 \mathrm{~m}$ depth east of Cape Forestier showing physical and nutrient parameters constructed from CTD casts. Fluorescence cross-sections are to $150 \mathrm{~m}$. ( $\mathbf{\nabla}$ ) Position of stations along transect (temperature, ${ }^{\circ} \mathrm{C}$; salinity, \%o; sigma- $\sigma_{i}$; nitrate, $\mu \mathrm{M}$; phosphate, $\mu \mathrm{M}$; fluorescence, FU) 


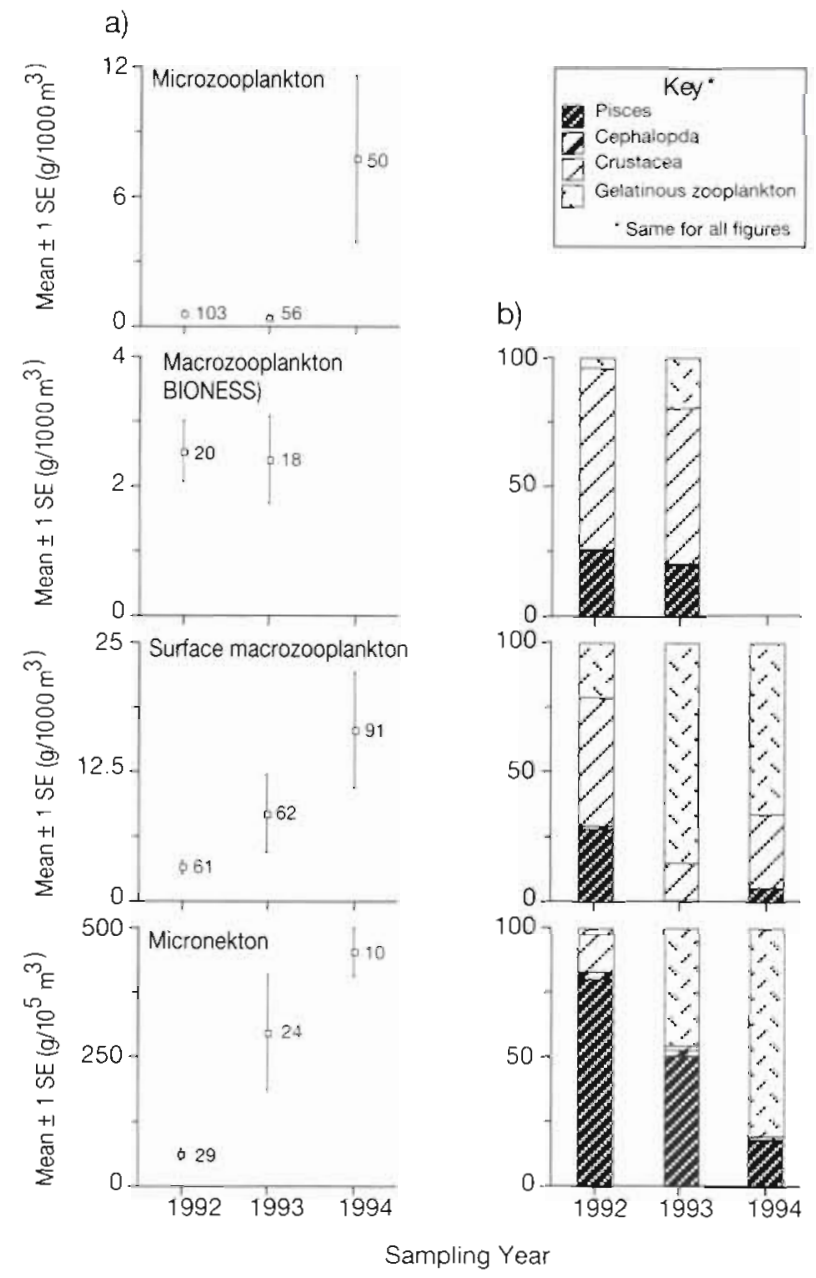

Fig. 4. (a) Comparison of biomass between years for microzooplankton, macrozooplankton and micronekton off eastern Tasmania (mean $\pm \mathrm{SE}_{i}$ number $=$ number of stations sampled); (b) percent contribution of the 4 main taxa to the total biomass by year

was a significant difference between areas. Due to a year/area interaction (Table 3, Fig. 5) we analysed the data separately for each year. The biomass over the shelf was significantly different from the other areas (Fig. 5. Table 4). Remarkably, in 1994 the biomass over the shelf was higher by a factor of 10 than in any other area in the 3 years (Fig. 5). This was due to large amounts of gelatinous zooplankton in some samples (one sample contained $770 \mathrm{~g}$ wet weight of gelatinous zooplankton).

Macrozooplankton. BIONESS net. No significant difference was found in zooplankton biomass between years or areas (Table 3, Fig. 6a), although over the shelf it was somewhat higher in 1992 than in 1993. The pattern in the percent contribution of the 4 main taxa over the 2 years was consistent (Fig. 6b). Crustacea made up the largest proportion of the macrozooplankton biomass during both years. However, in 1993 the biomass of SAW was dominated by gelatinous zooplankton.

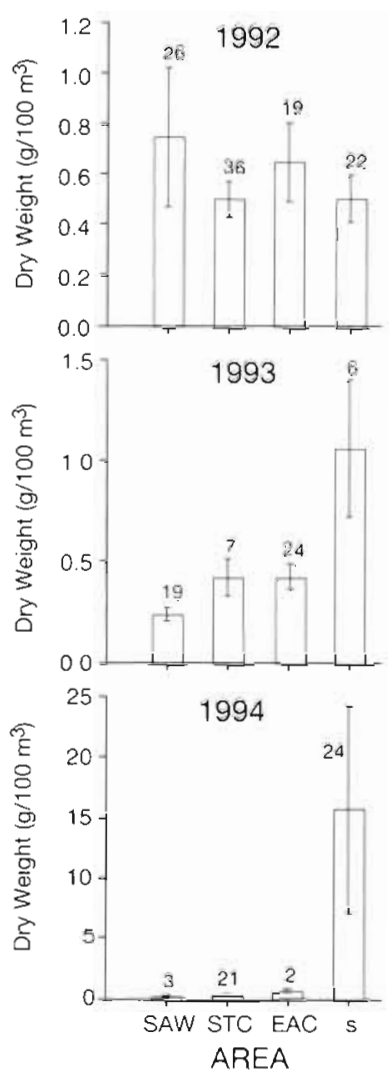

Fig. 5. Comparison of $\mathrm{ml}$ crozooplankton biomass by year off eastern Tasmania (mean $\pm \mathrm{SE}_{i}$ number $=$ number of stations sampled) SAW: subantarctic water; STC: subtropical convergence; EAC: East Australian Current; s: shelf

Bongo net. The biomass of samples collected from the left and right codends of the bongo net was not significantly different and so was combined for all subsequent analyses (ANOVA, $\mathrm{n}=136, \mathrm{df}=1, F=0.49, \mathrm{p}=0.49$ ). Biomass was significantly different between areas (Table 3, Fig. 7a), with biomass over the shelf significantly higher than that collected from the SAW (Tukey, $\bar{x}_{b}-\bar{x}_{a}$ $=0.98, q=3.77, \mathrm{df}=65$ ) and EAC (Tukey, $\bar{x}_{b}-\bar{x}_{d}=1.52$, $q=5.31, \mathrm{df}=6$ ). Gelatinous zooplankton dominated samples from SAW and shelf waters, whereas Crustacea was the main contributor to biomass collected from the EAC. Gelatinous zooplankton and Crustacea made up similar proportions of the biomass in STC (Fig. 7b)

Surface macrozooplankton (surface net). Macrozooplankton biomass was not significantly different between years but was significantly different between areas (Table 3, Fig 8a) However, because of the inter-

Table 4. Within-year comparisons of microzooplankton biomass (drop net) between areas (shelf, East Australian Current, subtropical convergence, subantarctic water) off eastern Tasmania using ANOVA

\begin{tabular}{|crrrrc|}
\hline Year & Source & $\mathrm{n}$ & $\mathrm{df}$ & F-ratio & $\mathrm{p}$ \\
\hline 1992 & Area & 103 & 3 & 0.32 & 0.81 \\
1993 & Area & 56 & 3 & 9.73 & 0.00 \\
1994 & Area & 50 & 3 & 3.51 & 0.02 \\
\hline
\end{tabular}


action between area and year, biomass was analysed separately each year. Biomass was highest over the shelf in all 3 years and was significantly higher than SAW and EAC water in 1993 and SAW in 1994 (Table 5). The shelf was dominated by gelatinous zooplankton in 1993 and 1994. The biomass in the SAW was dominated by the crustacean Euphausia spinifera in 1994 (Fig. 8a); that species comprised over $60 \%$ of the total biomass in that year.

\section{Micronekton (IYGPT midwater trawl)}

The biomass of micronekton differed significantly both between years and between areas with no significant year/area interaction (Table 3). Biomass in 1992 was significantly lower than that collected in 1993 and 1994 (Table 6) (Fig. 4). A Tukey post hoc test indicated that the SAW and shelf had a greater biomass than the EAC (Table 6, Fig. 9a). Gelatinous zooplankton was the dominant taxon collected from SAW and the STC, contributing more than $50 \%$ to the dry weight of the samples (Fig. 9b). In contrast, fish made up more than $50 \%$ of the biomass from the EAC water and the shelf.

Taken separately, the biomass of micronekton in 1992 was relatively consistent across areas (Table 7. Fig. 10a). In contrast, biomass was significantly different between areas in both 1993 and 1994 (Table 7). The biomass over the shelf in 1993 was greater than that of the EAC sampled in that year (Tukey, $\bar{x}_{b}-\bar{x}_{a}=3.18, q=$

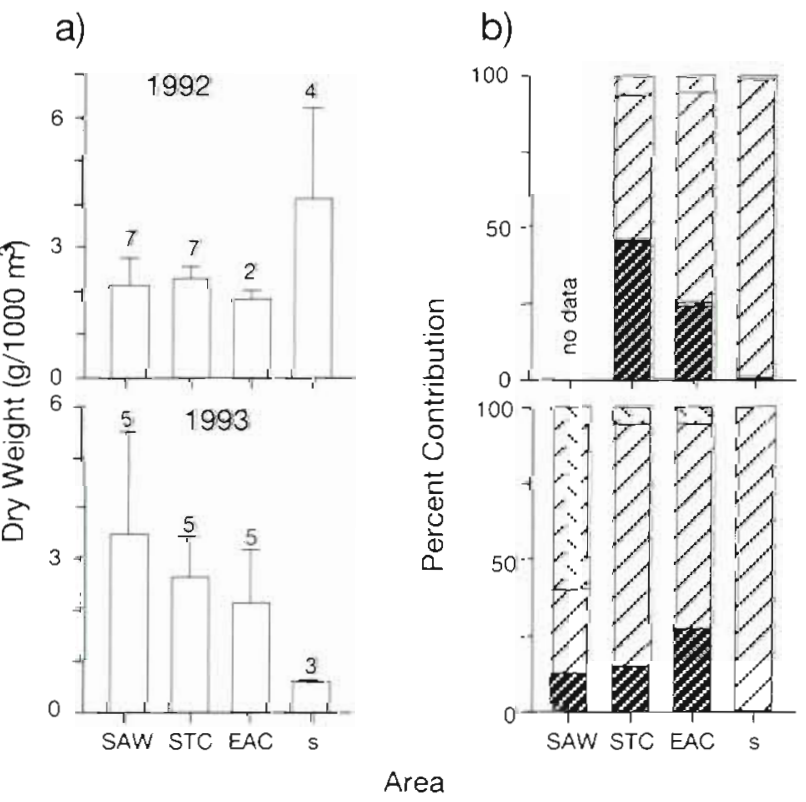

Fig. 6. (a) Comparison of macrozooplankton (BIONESS) biomass by area off eastern Tasmania (mean $\pm \mathrm{SE}_{i}$ number $=$ number of stations sampled); (b) percent contribution of the 4 main taxa to the total biomass by area (refer to key in Fig. 4) a)

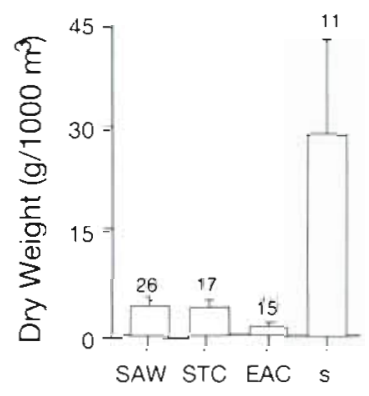

b)

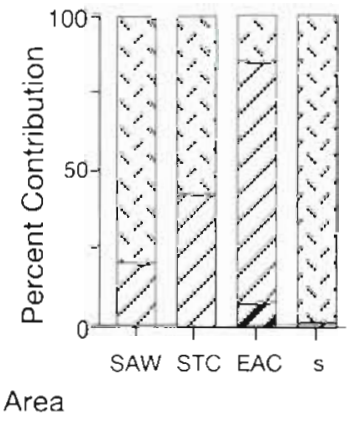

Fig. 7. (a) Comparison of macrozooplankton (bongo net) biomass by area of eastern Tasmania (mean $\pm \mathrm{SE}$; number = number of stations) (b) percent contribution of the 4 main taxa to the total biomass by area (refer to key in Fig. 4)

5.61, $\mathrm{df}=20$ ). There was a trend for higher biomass over the shelf than the SAW $(p=0.07)$. The shelf had a far greater percentage of fish taxa than the other areas sampled in 1993 (Fig. 10b). The main fish taxon over the shelf was jack mackerel Trachurus declivis. a)

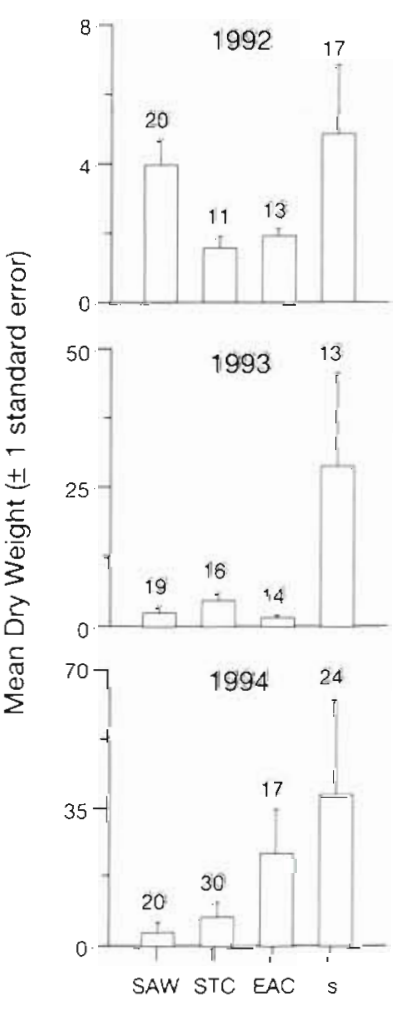

b)
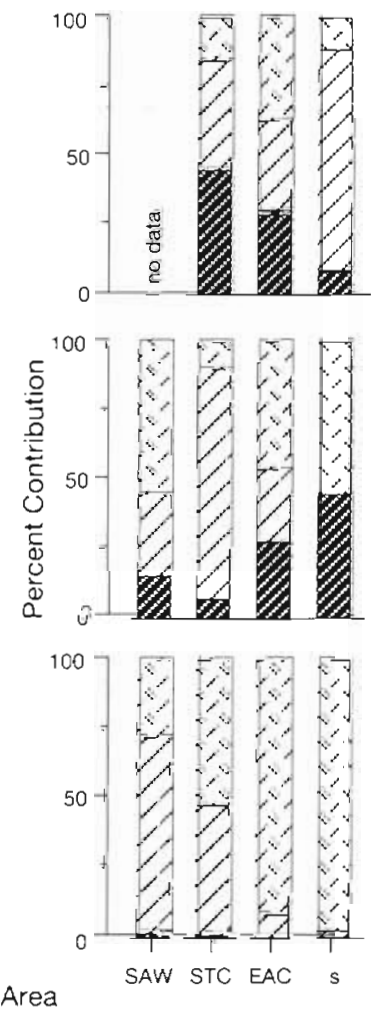

Fig. 8. (a) Comparison of surface macrozooplankton biomass by area off eastern Tasmania (mean $\pm S E_{i}$ number $=$ number of stations sampled); (b) percent contribution of the 4 main taxa to the total biomass by area (refer to key in Fig. 4) 
Table 5. Within-year comparisons of macrozooplankton biomass (surface net) between areas (shelf, East Australian Current, subtropical convergence, subantarctic water) off eastern Tasmania using ANOVA

\begin{tabular}{|cccccc|}
\hline Year & Source & $\mathrm{n}$ & $\mathrm{df}$ & F-ratio & $\mathrm{p}$ \\
\hline 1992 & Area & 61 & 3 & 2.59 & 0.06 \\
1993 & Area & 62 & 3 & 3.46 & 0.02 \\
1994 & Area & 91 & 3 & 2.78 & 0.05 \\
\hline
\end{tabular}

Table 6. Pairwise comparisons of micronekton biomass (IYGPT midwater trawl) by year and using the Tukey test. SAW: subantarctic water; EAC: East Australian Current

\begin{tabular}{|rccccc|}
\hline Test & $\bar{x}_{b}-\bar{x}_{\vec{\alpha}} \mid$ & SE & $q$ & Error df & $p$ \\
\hline $1993>1992$ & 1.81 & 0.23 & 7.84 & 51 & 0.00 \\
$1994>1992$ & 1.74 & 0.31 & 5.67 & 51 & 0.00 \\
Overall SAW > EAC & 1.34 & 0.29 & 4.58 & 51 & 0.02 \\
Shelf $>$ EAC & 2.12 & 0.38 & 5.64 & 51 & 0.01 \\
\hline
\end{tabular}

Table 7. Within-year comparisons of micronekton biomass (IYGPT midwater trawl) between areas (shelf, East Australian Current, subtropical convergence, subantarctic water) off eastern Tasmania using ANOVA

\begin{tabular}{|cccccc|}
\hline Year & Source & $\mathrm{n}$ & $\mathrm{df}$ & $F$-ratio & $\mathrm{p}$ \\
\hline 1992 & Area & 29 & 3 & 0.62 & 0.61 \\
1993 & Area & 24 & 3 & 5.72 & 0.00 \\
1994 & Area & 10 & 3 & 9.32 & 0.01 \\
\hline
\end{tabular}

Table 8. Comparisons of macrozooplankton biomass (BIONESS net) between depth strata $(0-100,100-200,200-300$, $300-400 \mathrm{~m}$ ) off eastern Tasmania using ANOVA

\begin{tabular}{|lccccc|}
\hline Year & Source & $\mathrm{n}$ & $\mathrm{df}$ & F-ratio & $\mathrm{p}$ \\
\hline Overall & Strata & 58 & 3 & 0.69 & 0.56 \\
1992 & Strata & 27 & 3 & 1.14 & 0.53 \\
1993 & Strata & 31 & 3 & 0.63 & 0.60 \\
\hline
\end{tabular}

A different pattern in biomass was evident in 1994 The biomass of the SAW was significantly greater than that of the EAC (Tukey, $\bar{x}_{b}-\bar{x}_{a}=2.50, q=6.85$, $\mathrm{df}=6$; Fig. 10a). The biomass of the SAW tended to be greater than that over the shelf $(p=0.06)$. Gelatinous zooplankton, with a few fish taxa, contributed most to the biomass within the SAW (Fig. 10b). The biomass of micronekton within the EAC, on the other hand, was composed mainly of the non-myctophid fish taxa Bathylagidae and Tetragonurus spp.

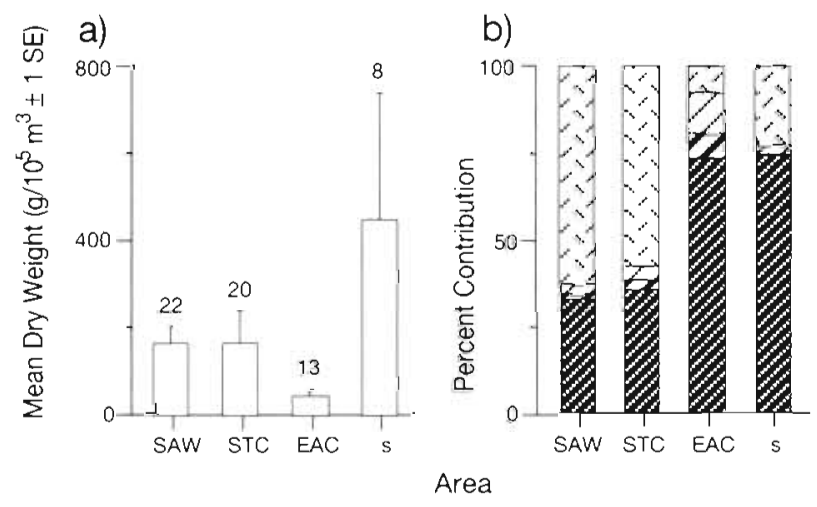

Fig. 9. (a) Comparison of micronekton (IYGPT) biomass by area off eastern Tasmania (mean $\pm \mathrm{SE}$ ). (b) Percent contribution of the 4 main taxa to the overall biomass by area (refer to key in Fig. 4)
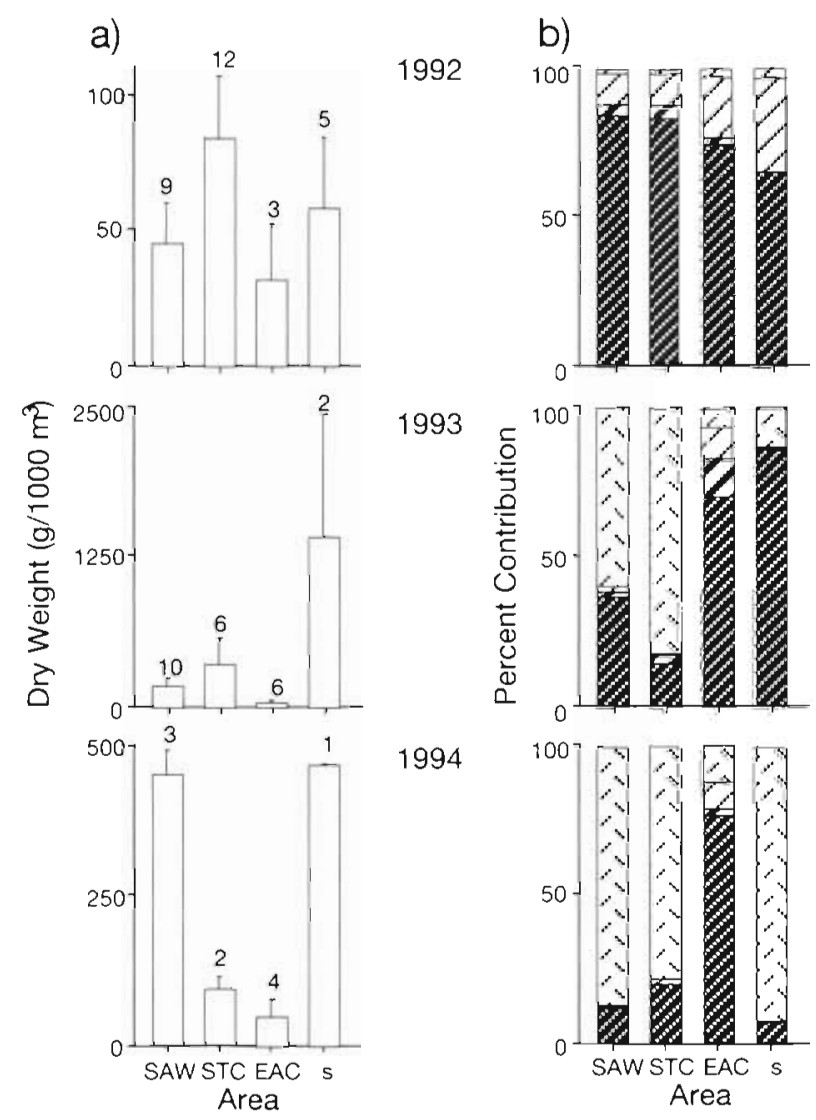

Fig. 10. (a) Comparison of micronekton (IYGPT) biomass by area off eastern Tasmania (mean $\pm \mathrm{SE}$; number $=$ number of stations sampled); (b) percent contribution of the 4 main taxa

to the total biomass by area (refer to key in Fig. 4)

\section{Vertical distribution of biomass}

Macrozooplankton biomass did not differ between strata either overall or within each year (Table 8 ). 


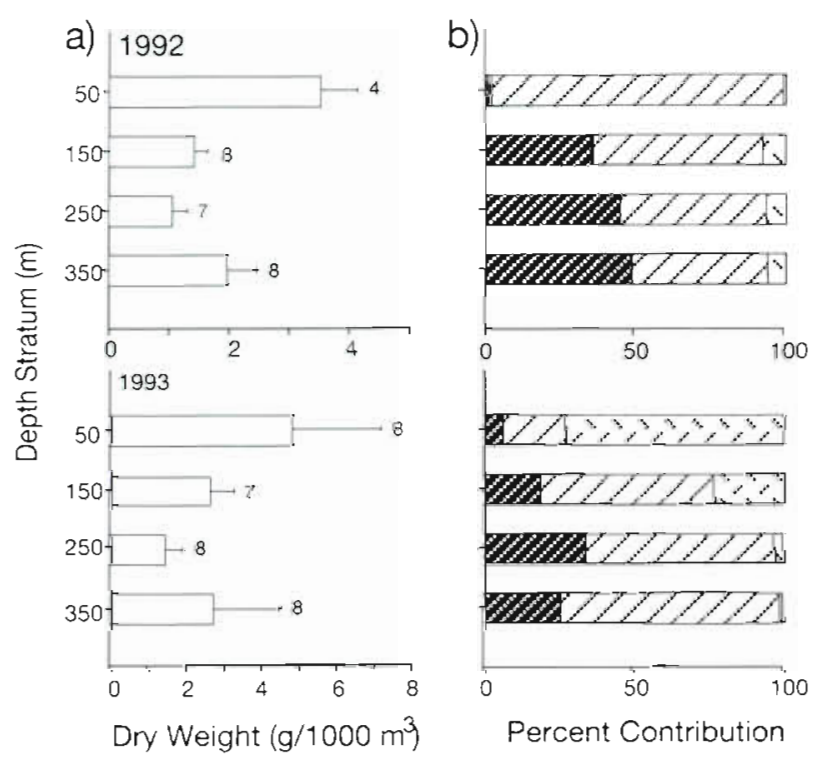

Fig. 11 (a) Vertical distribution of macrozooplankton (BIONESS) biomass off eastern Tasmania (number = number of samples per depth stratum); (b) percent contribution of the 4 main taxa to the total biomass per stratum (refer to key in Fig. 4)

Fig. 11 a suggests the biomass decreased slightly in the mid-strata in both years, but this was not significant. In 1992 the surface stratum was dominated by crustaceans (Fig 11b). In contrast, gelatinous zooplankton dominated surface waters in 1993. The lower strata contained an even mix of fish and Crustacea in both years (Fig. 11b).

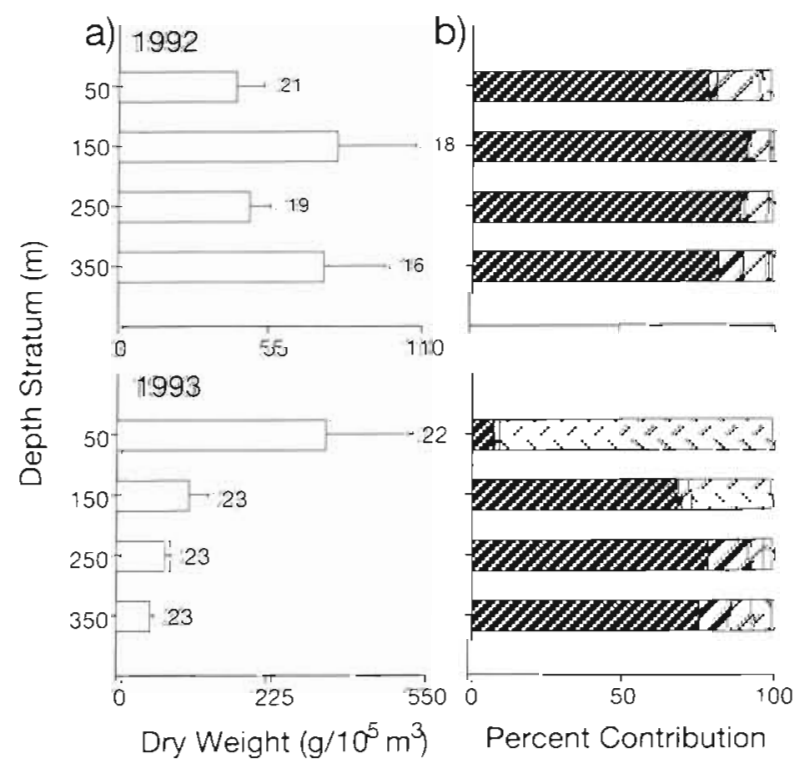

Fig. 12. (a) Vertical distribution of mictonekton (IYGPT) biomass off eastern Tasmania (number = number of samples per depth stratum): (b) percent contribution of the 4 main taxa to the total biomass per stratum (refer to key in Fig. 4)
The distribution of micronekton biomass with depth was similar in 1992 and 1993 (there was no depthstratified sampling in 1994) (Fig 12a) No significant differences in biomass with depth stratum were found within each year (ANOVA: $\mathrm{n}=74, \mathrm{df}=3, F=0.09$, $\mathrm{p}=0.97 ; \mathrm{n}=91, \mathrm{df}=3, F=0.59, \mathrm{p}=0.62 ; 1992$ and 1993 respectively).

Trachurus declivis, Bathylagidae, Lampichthys procerus, Lampanyctus australis and Diaphus danae were the most numerous fish taxa in the surface stratum during 1992, with progressively more Stomiiformes deeper in the water column. In 1993 the surface stratum was dominated by gelatinous zooplankton, which contributed substantially more to the biomass of the upper $200 \mathrm{~m}$ of the water column during 1993 than in 1992 (Fig. 12b). Fish, particularly Diaphus danae, Lampichthys procerus and Lampanyctus australis, dominated the lower stratum in that year.

\section{DISCUSSION}

\section{Importance of the shelf}

The relatively higher zooplankton biomasses we found inshore were similar to those found for other comparisons of inshore and offshore waters. This is not surprising, as production in coastal waters is generally higher than in open ocean waters, particularly in tropical and oligotrophic systems (e.g. Grice \& Hart 1962, Ortner et al. 1977. Tranter \& Kerr 1977, Wiebe et al. 1985), but also in temperate waters (Pillar 1986, Fiedler \& Bernard 1987). For example, in shelf waters of the central Californian (USA) coast, upwelling results in an environment rich in phytoplankton that supports fisheries for albacore Thunnus alalunga and skipjack tuna Katsuwonus pelamis (Fiedler \& Bernard 1987). Stomachs of albacore from this area contained a high percentage of krill Nyctiphanes simplex and anchovy Engraulis mordax (Bernard et al. 1985). Similarly, off South-Western Cape, South Africa, higher zooplankton biomasses have been reported for inshore compared with offshore waters (Pillar 1986). Important pilchard Sardinops ocellata and anchovy Engraulis capensis fisheries are also found in the same area (Shannon \& Field 1985)

The greater biomass in shelf waters off eastern Tasmania appears to be driven largely by the complex of currents that feed the shelf area. Satellite-tracked buoys revealed west coast water, augmented by river run-off, flowed eastward around Tasman Island onto the shelf during autumn (Cresswell et al. 1994). Added to this is the supply of nutrient-rich SAW driven onto the shelf by the prevailing southwesterly winds. Also, upward sloping of isopycnals along the inner edge of 
the EAC may draw nutrient-rich slope water onto the shelf (Harris et al. 1987). Our oceanographic transects identified a shelf-break front with relatively higher chlorophyll $a$, which indicated that upwelling was likely in the area. Significantly, autumn blooms of phytoplankton have previously been identified in the same region (Harris et al. 1987). The resulting primary production is food for large stocks of krill Nyctiphanes australis, which are most abundant at this time (Young et al. 1993). When the shelf waters of eastern Tasmania were displaced by the intrusion of EAC water in the austral summer-autumn of 1988/89, krill stocks (normally abundant at that time) were absent. The result was the collapse of the jack mackerel fishery that year (Young et al. 1993). A similar pattern of shelf-break upwelling off SW Africa, identified by upward-sloping isotherms, provides nutrients for large stocks of krill, including the congeneric species Nyctiphanes capensis (Barange \& Pillar 1992).

\section{Subtropical convergence}

One of the significant features of this study was the similarity in the biomass of the STC and the surrounding ocean waters (the only real difference was in 1994 when the micronekton biomass of the SAW was significantly higher than that of the surrounding water masses; Fig. 9a). This finding is in contrast to the many studies of oceanic fronts and eddies that have found such areas are sites of greater biomass and productivity (Uda 1973, Bradford et al. 1982, Roman et al. 1985, Heilmann et al. 1994). However, during autumn/winter (when this study was run) such increases in biomass were not always observed (see for example Pingree et al. 1976, 1978), apparently because the depth of the mixed layer increased, imposing a light limitation on the primary productivity. Nevertheless, in a recent study of the STC off South Africa during the austral winter, the biomass within the STC was higher than that of the surrounding waters (Pakhomov et al. 1994)

That the STC was not noticeably different from surrounding areas in the present study appears to be related to the weak gradients of physical (e.g. temperature and salinity) variables between the EAC and SAW Temperature changes of as little as $1^{\circ} \mathrm{C}$ per $18 \mathrm{~km}$ (10 $\mathrm{n}$ mile) were common and sharp discontinuities were rare. Enhanced biological activity, particularly primary productivity, along oceanic fronts is often related to the secondary circulation associated with the frontal region (Videau et al. 1994). For example, eddyforced upwelling is thought to be the single largest vector for the input of nitrate into surface waters of the Cape Hatteras, North Carolina (USA) region (Yoder et al. 1981). The lack of any strong gradients offshore may have limited the amount of such secondary circulation in waters off Tasmania. Also, the greater depth of the mixed layer, frequently reaching $300 \mathrm{~m}$ in winter (Harris et al. 1987), could result in lower productivity.

In contrast, the strong gradients along the shelf break observed during the 1992 and 1993 autumn cruises suggest upwelling in the shelf-break region. Harris et al. (1987) found an increase in nitrate and phytoplankton along the shelf during autumn, which they believed was linked to the movement of slope water onto the shelf. Occasional increases in phytoplankton biomass, associated with sharp gradients in physical variables, have been reported along the shelfbreak off Nova Scotia, Canada (Fournier et al. 1979). In 1994 SAW dominated the waters off the east coast of Tasmania both inshore and offshore, limiting the development of a shelf-break front.

\section{Vertical distribution}

In oceanic waters, the biomass of zooplankton generally decreases with depth (Angel \& Baker 1982, Wishner 1980). However, we found no evidence of such a decline over the depth ranges we sampled, but we did find that the composition of the biomass changed over the study period. The gelatinous zooplankton in the surface strata were more abundant in 1993 than 1992, while the relative composition of the main taxa changed little in the lower strata. Gelatinous zooplankton accounted in 1993 for about $90 \%$ of the micronekton biomass in the upper $100 \mathrm{~m}$. Although we did not sample with respect to depth strata in 1994 the continued presence of significant quantities of gelatinous zooplankton in oblique and surface hauls indicates that SAW was increasing in influence over the study period.

\section{Interannual differences}

Overlying the broad differences in biomass between inshore and offshore was a progressive increase in biomass over the 3 years (Fig. 4). This increase appeared to be the result of changes in the regional oceanography and may be related to the general wind strength. A roughly 10 yr cycle in westerly wind strength has been documented for this region (Pook 1992, Thresher 1994). Forecasting the strength of surface westerlies in the Tasmanian region has been linked to differences in geopotential height at $500 \mathrm{hPa}$ (Trenberth 1979. Pook 1992). The mean zonal index ( $\Delta$ geopotential height) calculated for the 5 mo (December to April) before each cruise increased progressively from about $545 \mathrm{dm}$ (decametres) in $1991 / 92$ to $580 \mathrm{dm}$ before the last 
cruise (M. J Pook unpubl. data). That the EAC moved offshore during the same period supports this view.

The increase in biomass over the study period was due largely to the increased numbers of gelatinous zooplankton, particularly in the upper stratum of the water column and on the shelf. Gelatinous zooplankton can respond quickly to increased nutrient loads through rapid reproduction linked with a short generation time (Heron 1972a, b, Deibel 1985, Kashkina 1986).

\section{Relationship between SBT and plankton}

The relationship between plankton stocks and tuna concentrations has previously been demonstrated on fine and broad scales (e.g Fiedler \& Bernard 1987, Roger 1994). Roger (1994) found that in the fishing grounds of tropical tunas, zooplankton biomass was 4 times higher than in latitudes to the south and north. He also found that the biomass of zooplankton, which are either prey or lead to prey of these tuna, was 7 times higher in the same area. Although no plankton data were presented, Hearn (1986) proposed that summer upwellings off South Australia provided an 'extensive area of nutrient-rich water [forming] the basis of a food chain that attracts SBT'.

Off eastern Tasmania, the only area where significantly higher biomasses of plankton were found was over the shelf. If we accept that the autumn/winter migration of SBT to areas off eastern Tasmania is in response to significant quantities of suitable prey, then the importance of the shelf becomes apparent. In an earlier study we found the biomass of krill Nyctiphanes australis over the shelf increased in autumn (Young et al. 1993), which led to schooling of their main predator, jack mackerel (Williams \& Pullen 1993), itself an important prey of SBT (Young et al. unpubl.) We suggest, therefore, that juvenile SBT time their migration eastward from south Australia to take advantage of the autumn production generated on the shelf. Fishery data indicate that by mid-winter the longline vessels have moved northward at a time when the krill stocks decline.

The link between krill, jack mackerel and SBT is well established for the inshore waters of eastern Tasmania. However, Nyctiphanes australis is rarely found offshore, while salps are distributed widely in inshore and offshore waters of southeastern Australia (Thompson 1948). Salps, which can respond rapidly to increases in nutrients and phytoplankton, act as a major energy store and also transfer nutrients to higher trophic levels (Deibel 1985, Caron et al. 1989). Salps may therefore provide one of the initial links between primary and secondary production in the early stages of offshore (and inshore) phytoplankton blooms
(Deibel 1985). Furthermore, in areas where nutrient and hydrographic requirements sustain high biomasses of salps for extended periods, salps themselves can play a significant and sometimes leading role in fish nutrition (Kashkina 1986, Heron et al. 1988). The presence of gelatinous zooplankton in the stomachs of SBT and their prey during the study period (Young et al. 1994) adds support to this idea.

In conclusion, nutrient-rich subantarctic and west coast water augmented by shelf-break upwelling appears to be linked to higher biomasses of zooplankton and micronekton over the shelf region. In particular, the shelf region is characterised by high biomasses of Nyctiphanes australis and gelatinous zooplankton both of which figure largely in the diet of jack mackerel, an important prey of SBT. Offshore, the pathway of energy transfer between primary production and top predators is less clear. However, gelatinous zooplankton may be an important link between primary production and SBT.

Addendum. A recent debate has arisen on the naming of the water masses we have described. It has been proposed that the subtropical convergence described herein may be the northern edge of a broader subtropical convergence zone (L. Clementsen, CSIRO, unpubl. data). Hence, what we have called subantarctic water may actually be the subtropical convergence zone

Acknowledgements. The authors thank the combined efforts of the skipper, fishing master and crew of FRV 'Southern Surveyor' This work was partly funded by Pasminco EZ Pty. Ltd. This paper benefited from the comments made by Alan Jordan, Tony Koslow, Barry Bruce, Vivienne Mawson and 3 anonymous reviewers.

\section{LITERATURE CITED}

Angel MV, Baker A de C (1982) Vertical distribution of the standing crop of plankton and micronekton at three stations in the northeast Atlantic. Biol Oceanogr 2:1-30

Barange M, Pillar SC (1992) Cross-shelf circulation, zonation and maintenance mechanisms of Nyctiphanes capensis and Euphausia hanseni (Euphausiacea) in the northern Benguela upwelling system. Cont Shelf Res 12:1027-1042

Bernard HJ, Hedgepeth JB, Reilly SB (1985) Stomach contents of albacore, skipjack and bonito caught off southern California during summer 1983. Calif Coop Oceanic Fish Invest Rep 26:175-182

Bradford JM, Heath RA, Chang FH, Hay CH (1982) The effect of warm-core eddies on oceanic productivity off northeastern New Zealand. Deep Sea Res 29:1501-1516

Caron DA, Madin LP, Cole JJ (1989) Composition and degradation of salp fecal pellets: implications for vertical flux in oceanic environments. J Mar Res 47:829-850

Cresswell G, Wells G, Peterson J (1994) Australian satellitetracked drifters 1991-1994. Report to Fisheries Research and Development Corporation (FRDC). CSIRO Division of Oceanography, Hobart

Deibel D (1985) Blooms of the pelagic tunicate, Dolioletta 
gegenbauri: are they associated with Gulf Stream fronta] eddies? J Mar Res 43:211-236

Dufor P, Stretta JM (1973) Fronts thermiques et thermohalins dans la région du Cap Lopez (Golfe de Guinée) juin-juillet 1972: phytoplancton, zooplancton, micronecton et pêche thonière. Cent Rech Océanogr Abidjan Doc Sci 4:99-142

Fiedler PC, Bernard HJ (1987) Tuna aggregation and feeding near fronts observed in satellite imagery. Cont Shelf Res $7: 871-881$

Fournier RO, van Det M, Wilson JS, Hargreaves NB (1979) Influence of the shelf-break front off Nova Scotia on phytoplankton standing stock in winter. Can J Fish Aquat Sci 36:1228-1237

Grice GD, Hart AD (1962) The abundance, seasonal occurrence and distribution of the epizooplankton between New York and Bermuda. Ecol Monogr 32:287-307

Harris G, Nilsson C, Clementson L, Thomas D (1987) The water masses of the east coast of Tasmania: seasonal and interannual variability and the influence on phytoplankton biomass and productivity. Aust J Mar Freshwat Res 38:569-590

Hearn WS (1986) Mathematical methods for evaluating marine fisheries. PhD thesis, University of NSW, Sydney

Heilmann JP, Richardson K, Ertebjerg G (1994) Annual distribution and activity of phytoplankton in the Skagerrak/ Kattegat frontal region. Mar Ecol Prog Ser 112:213-223

Heron AC (1972a) Population ecology of a colonizing species: the pelagic tunicate Thalia democratica 1 Individual growth rate and generation time. Oecologia 10:269-293

Heron AC (1972b) Population ecology of a colonizing species: the pelagic tuncate Thalsa democratica 2. Population and growth rate. Oecologia 10:294-312

Heron AC (1982) A vertical free fall net with no mouth obstruction. Limnol Oceanogr 27:380-383

Heron AC, McWilliam PS, Dal Pont J (1988) Length-weight relation in the salp Thalia democratica and potential of salps as a source of food. Mar Ecol Prog Ser 42:125-132

Jordan A, Pullen G. Marshall J, Williams H (1995) Temporal and spatial patterns of spawning in jack mackerel, Trachurus declivis (Pisces: Carangidae), during 1988-91 in eastern Tasmanian waters. Mar Freshwat Res 46:831-842

Kashkina AA (1986) Feednng of fishes on salps (Tunicata, Thaliacea). J Ichthyol 26:57-64

Kiørboe T, Johansen K (1986) Studies of a larval herring (Clupea harengus L.) patch in the Buchan area. IV Zooplankton distribution and productivity in relation to hydrographic features. Dana 6:37-51

Laurs RM, Fiedler PC, Montgomery DR (1984) Albacore tuna catch distributions relative to environmental features observed from satellites. Deep Sea Res 31:1085-1099

Loder JW, Platt T (1985) Physical controls on phytoplankton production at tidal fronts. In: Gibbs PE (ed) Proc 19th Eur Mar Biol Symp. Cambridge University Press, Cambridge, p 3-19

Omori M. Ikeda T (1984) Methods in marine zooplankton ecology. Wiley, New York

Ortner PB, Wiebe PH, Haury L, Boyd S (1977) Variability in zooplankton biomass distribution in the northern Sargasso Sea: the contribution of Gulf Stream cold core rings. Fish Bull US 76:323-334

Pakhomov EA, Perissinotto R, McQuaid CD (1994) Comparative structure of the macrozooplankton/micronekton communities of the Subtropical and Antarctic polar fronts. Mar Ecol Prog Ser 111:155-169

Pearcy WG, Krygier EE, Mesecar R, Ramsey F (1977) Vertical distribution and migration of oceanic micronekton off Ore- gon. Deep Sea Res 24:223-245

Peinert R, Miquel JC (1994) The significance of frontal processes for vertical particle fluxes: a case study in the Alboran Sea (SW Mediterranean Sea). J Mar Syst 5 $377-389$

Pillar SC (1986) Temporal and spatial variations in copepod and euphausiid biomass of the southern and southwestern coasts of South Africa in 1977/78. S Afr J Mar Scl $4: 219-229$

Pingree RD, Holligan PM, Mardell GT (1978) The effects of vertical stability on phytoplankton distributions in the summer on the northwest European shelf. Deep Sea Res 25:1011-1028

Pingree RD, Holligan PM, Mardell GT, Head RN (1976) The influence of physical stability on spring, summer and autumn phytoplankton blooms in the Celtic Sea. J Mar Biol Ass UK 56:845-873

Pook MJ (1992) A note on the variability of the midtropospheric flow over the Southern Ocean in the Australian region. Aust Meterol Mag 40:169-177

Roger C (1994) The plankton of the tropical western Indian ocean as a biomass indirectly supporting surface tunas (yellowfin, Thunnus albacares and skipjack, Katsuwonus pelamis). Environ Biol Fish 39:161-172

Roman MR, Gauzens AL, Cowles TJ (1985) Temporal and spatial changes in epipelagic microzooplankton and mesozooplankton biomass in warm-core Gulf Stream ring 82-B. Deep Sea Res 32:1007-1022

Shannon LV, Field JG (1985) Are fish stocks food-limited in the southern Benguela pelagic ecosystem? Mar Ecol Prog Ser 22:7-19

Shingu $C$ (1981) Ecology and stock of southern bluefin tuna Australian CSIRO Div Fish Oceanogr Rep 131

Thibault D, Gaudy R, Le Fèvre J (1994) Zooplankton biomass, feeding and metabolism in a geostrophic frontal area (Almeria-Oran Front, western Mediterranean). Significance to pelagic food webs. J Mar Syst 5:297-311

Thompson $H$ (1948) Pelagic tunicates of Australia. Commonwealth Council for Scientific and Industrial Research, Aus. tralia, Melbourne

Thresher R (1994) Climatic cycles may help explain fish recruitment in south east Australia. Aust Fish 53:20-22

Tranter DJ, Kerr JD (1977) Further studies of plankton ecosystems in the eastern Indian Ocean 3. Numerical abundance and biomass. Aust J Mar Freshwat Res 28:557-583

Trenberth KE (1979) Interannual variability of the $500 \mathrm{mb}$ zonal mean flow in the Southern Hemisphere. Mon Weather Rev 107:1515-1524

Uda M (1973) Pulsative fluctuation of oceanic fronts in association with the tuna fishing grounds and fisheries. J Fac Mar Sci Technol Tokai Univ 7:245-265

Videau C, Sournia A, Prieur L, Fiala M (1994) Phytoplankton and primary production characteristics at selected sites in the geostrophic Almeria-Oran front system (SW Mediterranean Sea). J Mar Syst 5:235-250

Wiebe PH, Boyd S, Cox JL (1975) Relationships between zooplankton displacement volume, wet weight, dry weight, and carbon. Fish Bull US 73:777-786

Wiebe PH, Flierl GR, Davis CS, Barber V, Boyd SH (1985) Macrozooplankton biomass in Gulf Stream warm-core rings: spatial distribution and temporal changes. J Geophys Res (C Oceans) 90:8885-8901

Williams $\mathrm{H}$, Pullen $\mathrm{G}$ (1993) Schooling behaviour of jack mackerel, Trachurus declivis (Jenyns), observed in the Tasmanian purse seine fishery. Aust J Mar Freshwat Res 44:577-587

Williams H, Pullen G, Kucerans G, Waterworth C (1987) 
The jack mackerel purse seine fishery in Tasmanıa, 1986-1987. Tech Rep Mar Lab Dep Sea Fish (Tasman) 19:1-32

Wishner KF (1980) The biomass of deep-sea benthopelagic plankton. Deep Sea Res 27:203-216

Wissing TE, Darnell RM, Ibrahim MA, Berner L (1973) Caloric values of marine anımals from the Gulf of Mexico. Contrib Mar Sci 17:1-7

Wyrtki K (1960) The surface circulation in the Coral and Tasman seas. Australian CSIRO Div Fish Oceanogr Tech Pap 8

Yamamoto T, Nishizawa S (1986) Small-scale zooplankton aggregations at the front of a Kuroshio warm-core ring. Deep Sea Res 33:1729-1740

Yoder JA, Atkinson LP, Lee TN, Kim HH, McClain CR (1981) Role of Gulf Stream frontal eddies in forming phytoplankton patches on the outer southeastern shelf. Limnol Oceanogr 26:1103-1110

Young JW, Blaber SJM (1986) Feeding ecology of three species of midwater fishes associated with the continental

This article was submitted to the editor slope of eastern Tasmania, Australia. Mar Biol 93:147-156 Young JW, Jordan AR, Bobbı C, Johannes RE, Haskard K Pullen G (1993) Seasonal and interannual vanability in krill (Nyctiphanes australis) stocks and their relationship to the fishery for jack mackerel (Trachurus declivis) off eastern Tasmania, Australia. Mar Biol 116:9-18

Young JW, Lamb TD, Bradford RW (in press) Distribution and community structure of midwater fishes in relation to the subtropical convergence off eastern Tasmania, Australia Mar Biol

Young JW, Lyne VD, Lamb TD, Bradford RW, Haskard K (1994) Distribution and food chain pathways of midwater fauna off eastern Tasmania. In: Research on jarosite dumping at sea: a program of research on jarosite dumping at sea by Pasminco Metals-EZ: physical dispersal of jarosite and surveys of marine biota heavy metal levels 1991/1994. CSIRO Australia, Hobart

Zar JH (1984) Biostatistical analysis. Prentice Hall, Englewood Cliffs, NJ

Manuscript first received: September 26, 1995

Revised version accepted: February 15, 1996 